\title{
Short communication: Determination of the whey protein index in milk protein concentrates
}

\author{
Zhengtao Zhao, ${ }^{1 *}$ Milena Corredig, ${ }^{1,2} \dagger$ and Zafir Gaygadzhiev ${ }^{3}$ \\ ${ }^{1}$ Department of Food Science, University of Guelph, Guelph, ON, N1G2W1, Canada \\ 2iFood Center, Department of Food Science, Aarhus University, Blichers Alle, Foulum, Denmark 8830 \\ ${ }^{3}$ Gay Lea Foods Co-operative Ltd., Guelph, ON, N1H 1J5, Canada
}

\section{ABSTRACT}

Milk protein concentrates are common ingredients in the dairy industry, with varying processing histories and composition. The objective of this research was to determine the feasibility of using the whey protein nitrogen (WPN) index, a well-established index for skim milk powder and nonfat dry milk, as a quality parameter for milk protein concentrates. The WPN index is a value based on the moisture-adjusted weight of skim milk powder. We hypothesized that WPN, even when standardized based on protein, may change depending on solubilization conditions of milk protein concentrates because of differences in solubilization conditions or processing history. The WPN was measured for model concentrates with different thermal history or reconstitution conditions. The WPN was not affected by an increased concentration of soluble casein in the dispersions nor after solubilization of the powder at 22 or $60^{\circ} \mathrm{C}$. All reconstituted samples were standardized for protein. The WPN was also in full accordance with residual native protein measured by chromatography. Key words: whey protein nitrogen index, milk powder quality parameter, milk protein concentrate

\section{Short Communication}

Milk protein concentrates are commonly used as ingredients in food and they are widespread in terms of composition, processing history, quality, and technofunctionality. The thermal history during the production of milk powders, such as preheating of milk, pasteurization, and spray drying, results in changes that may include the denaturation of whey proteins, precipitation of soluble calcium and phosphate, and formation

\footnotetext{
Received February 26, 2019.

Accepted May 12, 2019.

*Current address: Parmalat Canada, Research and Development, London, ON, N6B 1N8, Canada.

†Corresponding author: mc@food.au.dk
}

of heat-induced aggregates, in both the dispersed and colloidal phases (Oldfield et al., 2005; Singh, 2011). The extent of whey protein denaturation affects the functional properties of obtained milk powder products, such as solubility, emulsification, water holding, foaming, and gelling properties (Pearce, 1995; Mimouni et al., 2010; Singh, 2011). Although this is well known for skim milk powder, much less has been reported on milk protein concentrates. It is essential to have quality parameters to categorize protein concentrates in terms of their extent of thermal history, because this may assist in providing the correct ingredient targeted to a certain end use.

In the dairy industry, the whey protein nitrogen index (WPNI) has been used as a means to classify skim milk powder (SMP) and nonfat dry milk. This method is based on the principle of salting out the denatured soluble serum protein followed by acid-induced aggregation of the remaining soluble whey proteins; this second step causes an increase in turbidity (Kuramoto et al., 1959; Anonymous, 1971). The turbidity of the final suspension is then assessed against a standard curve and related to the amount of residual native protein, per gram of powder, corrected for its moisture content to a reference moisture of $3.16 \%$. Skim milk powder is classified as a low-, medium- or high-heat SMP at WPNI values of $>6.0,1.5$ to 6.0 , and $<1.5(\mathrm{mg} / \mathrm{g}$ of powder), respectively (Anonymous, 1971). The values obtained from WPN (distinct from WPNI, which is the index in $\mathrm{mg} / \mathrm{g}$ of powder) for skim milk have been shown to approximate chromatographic measurements (Manji and Kakuda, 1987). Furthermore, previous research reported that the development of turbidity from the WPNI method was affected by the ratio of $\alpha$-LA and $\beta$-LG (Sanderson, 1970). It was recently reported that standardization of milk powder with lactose or permeate affects the measurement of WPNI and, in some cases, may change the heat classification of milk powders (Sikand et al., 2008). Considering a protein content for skim milk of about $35 \%$ (wt/wt), a WPN value $>17$ (mg/g of protein; distinct from WPNI, which 
is $\mathrm{mg} / \mathrm{g}$ of powder) would classify SMP as low heat. It has been suggested (Sikand et al., 2008) that a better way to calculate WPNI would be to express the values on a protein basis instead of a solids basis (i.e., soluble whey protein nitrogen per gram of protein instead of per gram of powder).

Compared with SMP, milk protein concentrates (MPC) can vary in protein-to-solids ratio, as well as in the amount of lactose and other minerals present. They are produced by UF and diafiltration, followed by spray drying of skim milk (Anema et al., 2006). The powders vary not only in terms of solids-to-protein ratio (while maintaining the ratio of caseins to whey proteins), but also in terms of processing history or reconstitution conditions. Furthermore, processing steps aimed at modifying the functionality of the proteins are often carried out to add value to MPC products (Corredig et al., 2019). For example, preacidification of milk (Eshpari et al., 2016), addition of monovalent salts (Sikand et al., 2016), and addition of chelating agents (McCarthy et al., 2017) or sodium caseinate (Schokker et al., 2011) have been reported to change the solubility of the powders. Recent studies have demonstrated that the amount of soluble caseins present in the suspensions may be affected by reconstitution conditions and processing history (Crowley et al., 2015; Eshpari et al., 2016; Lin et al., 2018). It is unclear therefore whether the WPN can be also used to classify MPC powders subjected to different processing. In this study, we tested a model milk protein concentrate (MPC70) treated under different conditions to evaluate whether different concentrations of soluble caseins and complexes present in MPC70 dispersions affect the estimation of the WPN, which was estimated as milligrams of whey protein $\mathrm{N}$ per gram of protein.

Milk protein concentrate powders with high protein content may have poor solubility. For example, it was reported that MPC85 (i.e., $\sim 85 \%$ protein) can achieve only $53 \%$ solubility after $2 \mathrm{~d}$ of storage at $20^{\circ} \mathrm{C}$ (Havea, 2006). Solubilizing high-protein MPC at temperatures above $60^{\circ} \mathrm{C}$ is recommended (Martin et al., 2010). It is unclear whether the measurement of WPN is affected by using such reconstitution temperatures.

The objective of this research was to investigate the effect of different reconstitution methods on the WPN. Chromatography was also used to measure the concentration of residual native protein. Heat treatment was applied to a model milk protein concentrate to verify the changes in WPN.

Low-, medium- and high-heat SMP, MPC70, and sodium caseinate (NaCas) were obtained from Gay Lea Foods Co-Operative Ltd. (Guelph, ON, Canada). Four reconstitution methods were adopted to reconstitute MPC70: stirring at $22^{\circ} \mathrm{C}$ for 1 or $4 \mathrm{~h}$, stirring at $60^{\circ} \mathrm{C}$ for $30 \mathrm{~min}$, or blending at a speed of $1,000 \mathrm{rpm}$ for 5 min at $60^{\circ} \mathrm{C}$ using a household kitchen blender (Black \& Decker, Towson, MD). The particle size distribution was measured after sample preparation using integrated light scattering (Mastersizer S, Malvern, Southborough, MA) using refractive indices of 1.39 and 1.33 for casein and water, respectively. Selected reconstituted samples were heated at 75 or $85^{\circ} \mathrm{C}$ for $10 \mathrm{~min}$ or had different amounts of sodium citrate (NaCit; 2.5 and 5.0 $\mathrm{mmol} \cdot \mathrm{L}^{-1}$ ) or sodium caseinate (NaCas; $0.5 \%$ and $1 \%$, wt/wt) added to them to increase the ratio of soluble to colloidal casein.

To produce powders of controlled processing history, liquid MPC70 (total protein $13.3 \pm 0.2 \%$ and total solid $18.8 \pm 0.1 \%$, wt/wt) was provided by Gay Lea Foods Co-Operative Ltd. The MPC70 was produced from skimmed pasteurized milk in a production facility (Teeswater, ON, Canada). The MPC70 was then further heated at $72^{\circ} \mathrm{C}$ for $16 \mathrm{~s}$ or $85^{\circ} \mathrm{C}$ for 7 min using a pilot-scale heating system (Microthermics, Raleigh, $\mathrm{NC}$ ) or $0.56 \%$ NaCas was added to the fresh MPC70 by stirring overnight at $4^{\circ} \mathrm{C}$ to reach a casein concentration of $4 \%$ of total milk protein in the powder. The sample without further treatment was used as control. A Buchi B-290 compact laboratory spray dryer was used to spray-dry the suspensions (Büchi Labortechnik AG, Flawil, Switzerland; inlet temperature $175^{\circ} \mathrm{C}$, outlet temperature $85^{\circ} \mathrm{C}$, pump speed $60 \%$ ).

The WPN was obtained using the standard method (Anonymous, 1971). In brief, $2 \mathrm{~g}$ of SMP was dissolved in $20 \mathrm{~g}$ of water, and then $8 \mathrm{~g}$ of $\mathrm{NaCl}$ was added to the skim milk and incubated for 30 min at $37^{\circ} \mathrm{C}$. The solution was then filtered and the clear filtrate was diluted 11 times with saturated $\mathrm{NaCl}$ before adding approximately $200 \mu \mathrm{L}$ of $\mathrm{HCl}(10 \% \mathrm{wt} / \mathrm{vol})$ to develop turbidity. The amount of residual protein in the supernatant was then estimated from a standard curve based on the turbidity measurements.

The residual native whey protein was also quantified using chromatography (Vasbinder and de Kruif, 2003). In this case, $2 \mathrm{~g}$ of SMP or $0.95 \mathrm{~g}$ of MPC70 was dissolved in $20 \mathrm{~g}$ of deionized water under stirring for 4 $\mathrm{h}$ at room temperature $\left(22^{\circ} \mathrm{C}\right)$ to obtain a suspension with $3.20 \%$ protein (wt/vol). To remove all the caseins and denatured whey proteins, $0.4 \mathrm{~g}$ of the reconstituted suspension was diluted with $0.8 \mathrm{~g}$ of distilled water and acidified with $40 \mu \mathrm{L}$ of a $10 \%$ acetic acid solution. After $10 \mathrm{~min}, 40 \mu \mathrm{L}$ of sodium acetate $\left(1 \mathrm{~mol} \cdot \mathrm{L}^{-1}\right)$ and $0.72 \mathrm{~g}$ of distilled water were added. The solution was then centrifuged for $10 \mathrm{~min}$ at 4,000 $\times g$ (Eppendorf centrifuge-5415D, Brinkmann Instruments Ltd., Mississauga, ON, Canada).

The residual protein in the supernatant was analyzed using an AKTA purifier (900 series, GE Biosciences, 
Baie d'Urfé, Quebec, Canada), equipped with a UV900 detector (set to $280 \mathrm{~nm}$ ). A 1-mL Hitrap SP HP cation exchange chromatography column (GE Biosciences) was used to separate $\alpha-\mathrm{LA}$ and $\beta-\mathrm{LG}$, using $20 \mathrm{mmol} \cdot \mathrm{L}^{-1}$ citric acid (buffer A) and $20 \mathrm{mmol} \cdot \mathrm{L}^{-1}$ citric acid containing $1 \mathrm{~mol} \cdot \mathrm{L}^{-1} \mathrm{NaCl}$ (buffer B), at $\mathrm{pH}$ 3.60. The separation was conducted at a flow rate of $1 \mathrm{~mL} \cdot \mathrm{min}^{-1}$ using a gradient elution from 0 to $41 \% \mathrm{~B}$ (buffer B) in $6 \mathrm{~min}$, from 41 to $45 \% \mathrm{~B}$ in $2 \mathrm{~min}, 45 \%$ $\mathrm{B}$ in $5 \mathrm{~min}$, from 45 to $100 \% \mathrm{~B}$ in $10 \mathrm{~min}$, and $100 \%$ B for $10 \mathrm{~min}$. Standards using protein purified in the laboratory were used to build the calibration curves. The native whey protein value (WPN) was determined in milligrams per gram of protein.

Powders were dissolved as indicated above, and the size distribution for the reconstituted MPC70 suspensions was measured using integrated light scattering (Figure 1). Dispersing powder at $22^{\circ} \mathrm{C}$ resulted in 2 populations of particles, one $<1.0 \mu \mathrm{m}$ in diameter and the other between 10 and $200 \mu \mathrm{m}$. The presence of large particles indicated that at room temperature (the conditions used), up to $1 \mathrm{~h}$ of mixing was not sufficient to fully solubilize the casein micelles. The results are in full agreement with previous research (Ferrer et al., 2008; Mimouni et al., 2009). The low solubility of highprotein milk concentrates is well known, particularly for MPC with protein content $>70 \%$ (Anema et al., 2006; Havea, 2006). The higher temperature, $60^{\circ} \mathrm{C}$, noticeably improved the solubilization of MPC70. The average volume weighted diameter $\left(\mathrm{D}_{[4.3]}\right)$ value was $0.147 \pm 0.02 \mu \mathrm{m}$ at $60^{\circ} \mathrm{C}$ compared with $23.6 \pm 1.18$ $\mu \mathrm{m}$ at $22^{\circ} \mathrm{C}$, regardless of the method (stirring for 30 min or blending for $5 \mathrm{~min}$ ), in agreement with previous publications (Martin et al., 2010; Eshpari et al., 2016). Different solubilization methods (room temperature vs. $60^{\circ} \mathrm{C}$ for 30 or $5 \mathrm{~min}$ ) were tested to determine their effects on WPN.

The MPC70 was solubilized using water (control or heat-treated samples) or water with $\mathrm{NaCit}$ (known to chelate colloidal calcium) or NaCas to vary the amount of nonmicellar casein present in the suspension. Table 1 summarizes the WPN values determined using the standard turbidimetric method. The control MPC70 reconstituted at room temperature had a WPN value of $22.8 \pm 0.3 \mathrm{mg} \cdot \mathrm{g}^{-1}$ of protein. The WPN for the MPC70 dissolved at $60^{\circ} \mathrm{C}$ was not significantly different from the control MPC. Moreover, we detected no significant differences between stirring for $30 \mathrm{~min}$ and blending for $5 \mathrm{~min}$. Although the addition of $\mathrm{NaCit}$ or NaCas resulted in a significant increase of soluble caseins, the measurement of WPN was not affected, which further confirms that turbidity develops solely from the residual whey protein. Finally, the presence of soluble casein and possible heat-induced interactions between whey

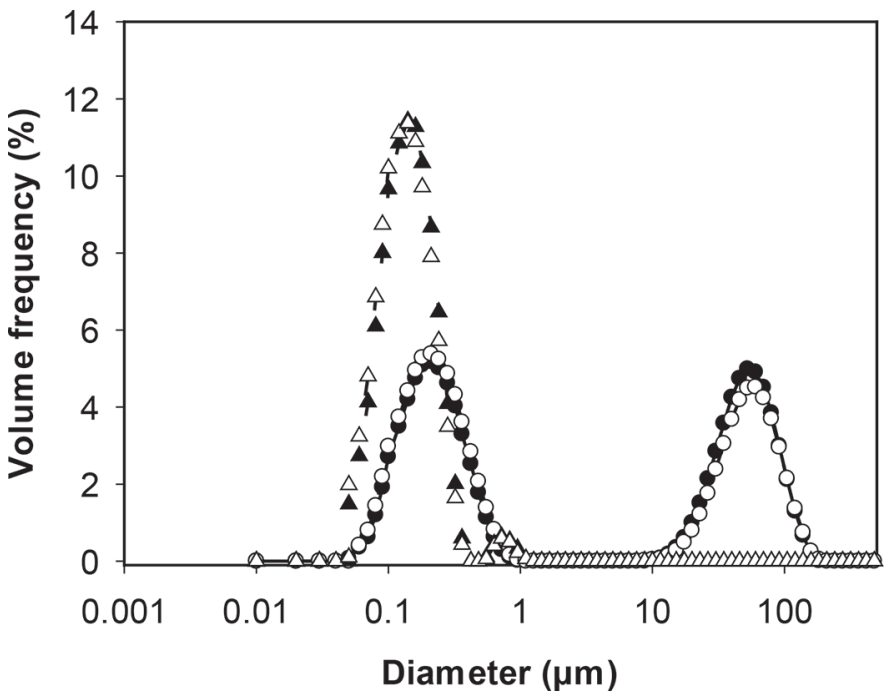

Figure 1. Particle size distribution of milk protein concentrate (MPC70) solution prepared by different dissolution methods: room temperature for $1 \mathrm{~h}(\bullet)$, room temperature for $4 \mathrm{~h}(\bigcirc), 60^{\circ} \mathrm{C}$ for 30 $\min (\boldsymbol{\Lambda})$ and $60^{\circ} \mathrm{C}$ blended for $5 \min (\Delta)$.

proteins and caseins in solution during solubilization at $60^{\circ} \mathrm{C}$ for $30 \mathrm{~min}$ did not affect measurement of the WPN.

To confirm that heating MPC70 will decrease the WPN, MPC70 suspensions were subjected to heat treatments, as shown in Table 1. The WPN of MPC 70 decreased to $13.7 \pm 0.6$ and $5.1 \pm 0.3 \mathrm{mg} \cdot \mathrm{g}^{-1}$ after heating the suspensions for $10 \mathrm{~min}$ at $75^{\circ} \mathrm{C}$ and $85^{\circ} \mathrm{C}$, respectively, indicating that substantial whey protein denaturation occurs at these temperatures (Anema and McKenna, 1996). The same results were shown for fresh preheated MPC70 or fresh MPC70 with added NaCit or NaCas before drying.

Table 1. Effect of sodium citrate, sodium caseinate, and heat treatment on whey protein nitrogen (WPN; $\mathrm{mg} \cdot \mathrm{g}^{-1}$ protein), measured using the conventional turbidimetric method for milk protein concentrate (MPC70) powder prepared using different reconstitution methods ${ }^{1}$

\begin{tabular}{lccc}
\hline & \multicolumn{3}{c}{ Reconstitution method } \\
\cline { 2 - 4 } Treatment $^{2}$ & $22^{\circ} \mathrm{C}, 30 \mathrm{~min}$ & $60^{\circ} \mathrm{C}, 30 \mathrm{~min}$ & $60^{\circ} \mathrm{C}$, blended \\
\hline Control & $22.8 \pm 0.3^{\mathrm{a}}$ & $21.8 \pm 0.1^{\mathrm{a}}$ & $21.2 \pm 0.2^{\mathrm{a}}$ \\
NaCit $(2.5 \mathrm{mM})$ & $22.9 \pm 0.2^{\mathrm{a}}$ & $21.8 \pm 0.6^{\mathrm{a}}$ & $20.6 \pm 0.4^{\mathrm{a}}$ \\
$\mathrm{NaCit}(5.0 \mathrm{mM})$ & $23.1 \pm 0.2^{\mathrm{a}}$ & $21.5 \pm 0.2^{\mathrm{a}}$ & $20.9 \pm 0.5^{\mathrm{a}}$ \\
$\mathrm{NaCas}(0.5 \%)$ & $23.0 \pm 0.3^{\mathrm{a}}$ & $20.9 \pm 0.1^{\mathrm{a}}$ & $20.7 \pm 0.3^{\mathrm{a}}$ \\
NaCas $(1.0 \%)$ & $22.7 \pm 0.6^{\mathrm{a}}$ & $21.3 \pm 0.2^{\mathrm{a}}$ & $21.0 \pm 0.4^{\mathrm{a}}$ \\
$75^{\circ} \mathrm{C}, 10 \mathrm{~min}$ & $13.7 \pm 0.6^{\mathrm{b}}$ & $13.8 \pm 0.1^{\mathrm{b}}$ & $13.6 \pm 0.4^{\mathrm{b}}$ \\
$85^{\circ} \mathrm{C}, 10 \mathrm{~min}$ & $5.1 \pm 0.3^{\mathrm{c}}$ & $5.00 \pm 0.2^{\mathrm{c}}$ & $5.0 \pm 0.1^{\mathrm{c}}$ \\
\hline
\end{tabular}

${ }^{\mathrm{a}-\mathrm{C}}$ Values not sharing a common superscript differ significantly $(P<$ $0.05)$.

${ }^{1}$ Values are presented as the means \pm SD of 3 separate experiments.

${ }^{2}$ Sodium citrate ( $\mathrm{NaCit}$ ) or sodium caseinate (NaCas) were added to the suspensions to increase the ratio of soluble to colloidal casein. 
Table 2. Total protein, moisture, and whey protein N (WPN; $\mathrm{mg} \cdot \mathrm{g}^{-1}$ protein) measured with the conventional method and by chromatography for fresh milk concentrate and reconstituted milk protein concentrate (MPC70) powders produced from different pretreatments ${ }^{1}$

\begin{tabular}{|c|c|c|c|c|}
\hline \multirow[b]{2}{*}{ Sample } & \multirow[b]{2}{*}{ Total protein (\%) } & \multirow[b]{2}{*}{ Moisture (\%) } & \multicolumn{2}{|c|}{ WPN (mg.g $\left.{ }^{-1}\right)$} \\
\hline & & & Conventional & Chromatography \\
\hline \multicolumn{5}{|l|}{ Fresh } \\
\hline Control & $13.1 \pm 0.2^{\mathrm{a}}$ & $\mathrm{NA}^{2}$ & $23.5 \pm 0.4^{\mathrm{a}}$ & $23.3 \pm 0.6^{\mathrm{a}}$ \\
\hline $72^{\circ} \mathrm{C}, 16 \mathrm{~s}$ & $13.1 \pm 0.4^{\mathrm{a}}$ & $\mathrm{NA}$ & $22.6 \pm 0.9^{\mathrm{a}}$ & $22.3 \pm 0.3^{\mathrm{ac}}$ \\
\hline $85^{\circ} \mathrm{C}, 7 \mathrm{~min}$ & $13.2 \pm 0.2^{\mathrm{a}}$ & NA & $4.4 \pm 0.1^{\mathrm{b}}$ & $3.9 \pm 0.2^{\mathrm{b}}$ \\
\hline $\mathrm{NaCas}^{3}$ added & $13.6 \pm 0.0^{\mathrm{b}}$ & $\mathrm{NA}$ & $23.1 \pm 0.3^{\mathrm{a}}$ & $21.9 \pm 0.2^{\mathrm{c}}$ \\
\hline \multicolumn{5}{|l|}{ Powder } \\
\hline Control & $68.3 \pm 0.1^{\mathrm{c}}$ & $3.5 \pm 0.2^{\mathrm{a}}$ & $22.8 \pm 0.9^{\mathrm{a}}$ & $19.8 \pm 0.4^{\mathrm{d}}$ \\
\hline $72^{\circ} \mathrm{C}, 16 \mathrm{~s}$ & $68.1 \pm 0.1^{\mathrm{c}}$ & $3.6 \pm 0.4^{\mathrm{a}}$ & $15.7 \pm 0.7^{\mathrm{a}}$ & $18.5 \pm 0.1^{\mathrm{e}}$ \\
\hline $85^{\circ} \mathrm{C}, 7 \mathrm{~min}$ & $68.2 \pm 0.1^{\mathrm{c}}$ & $3.2 \pm 0.2^{\mathrm{a}}$ & $4.4 \pm 0.2^{\mathrm{b}}$ & $3.6 \pm 0.3^{\mathrm{b}}$ \\
\hline $\mathrm{NaCas}$ added & $68.3 \pm 0.1^{\mathrm{c}}$ & $3.7 \pm 0.4^{\mathrm{a}}$ & $23.3 \pm 0.5^{\mathrm{a}}$ & $19.4 \pm 0.7^{\mathrm{d}}$ \\
\hline
\end{tabular}

Table 2 shows the results of WPN measured using the conventional method and that measured by chromatography, as well as the estimation of residual whey protein using a standard curve. All MPC70 samples were reconstituted at room temperature for $1 \mathrm{~h}$ before analysis. Table 2 also shows the composition of the various samples before and after drying. All powders were dissolved to a protein concentration of $3.2 \%$ to better compare the results. Fresh samples showed similar values of WPN after a second pasteurization $\left(72^{\circ} \mathrm{C}, 16 \mathrm{~s}\right)$ and after the addition of NaCas. The WPN values ranged from 22 to $24 \mathrm{mg} \cdot \mathrm{g}^{-1}$ of protein, in agreement with the results of Table 1 . In contrast, the fresh samples further heated at $85^{\circ} \mathrm{C}$ for 7 min showed a significant reduction in WPN value to $4.5 \mathrm{mg} \cdot \mathrm{g}^{-1}$ protein. Statistical analysis of the WPN values for the same samples after spray drying and reconstitution showed no difference between fresh, dried, and reconstituted samples (Table 2).

The amount of residual soluble whey protein measured by chromatography is shown in Table 2 . We detected no significant differences when comparing the conventional WPN and that obtained by chromatography, confirming the feasibility of the conventional WPN method for milk protein concentrates. We concluded that the presence of small molecules such as phospholipids and small peptides that contribute to the development of turbidity in the method of WPN could be ignored when samples are reconstituted at protein levels similar to that of skim milk.

The WPN measured by chromatography showed smaller experimental variations and demonstrated a small decrease in the amount of soluble whey protein after reconstitution (Table 2). All values obtained for the MPC reconstituted powder were within the range of a low-heat powder except for the MPC treated at $85^{\circ} \mathrm{C}$ for $7 \mathrm{~min}$, which would be classified as a high-heat powder.

In this study, we confirmed that the conventional WPN method could be used for milk protein concentrates; however, it is necessary to standardize the powder based on protein content to compare the thermal history of the concentrates. This would not apply to isolates with different ratios of whey protein to caseins.

\section{ACKNOWLEDGMENTS}

The research was funded by the Mitacs Elevate Postdoctoral program (Toronto, Canada) and the Natural Science and Engineering Council of Canada (Ottawa, Canada), under the Industrial Research Chair program. The authors also thank Gay Lea Foods (Mississauga, Canada) for the in-kind contribution to this project.

\section{REFERENCES}

Anema, S. G., and A. McKenna. 1996. Reaction kinetics of thermal denaturation of whey proteins in heated reconstituted whole milk. J. Agric. Food Chem. 44:422-428.

Anema, S. G., D. N. Pinder, R. J. Hunter, and Y. Hemar. 2006. Effects of storage temperature on the solubility of milk protein concentrate (MPC85). Food Hydrocoll. 20:386-393.

Anonymous. 1971. Standards for grades of dry milks including methods of analysis. American Dairy Products Institute Bulletin 916.

Corredig, M., P. Krishnakutti Nair, Y. Li, H. Eshpari, and Z. Zhao. 2019. Invited review: Understanding the behaviour of caseins in milk concentrates. J. Dairy Sci. 102:4772-4782. https://doi.org/10 $.3168 /$ jds.2018-15943.

Crowley, S. V., B. Desautel, I. Gazi, A. L. Kelly, T. Huppertz, and J. A. O'Mahony. 2015. Rehydration characteristics of milk protein concentrate powders. J. Food Eng. 149:105-113. 
Eshpari, H., P. S. Tong, and M. Corredig. 2016. Changes in particle size, calcium and phosphate solubilization, and microstructure of rehydrated milk protein concentrates, prepared from partially acidified milk. Dairy Sci. Technol. 96:329-343.

Ferrer, M. A., A. R. Hill, and M. Corredig. 2008. Rheological properties of rennet gels containing milk protein concentrate. J. Dairy Sci. 91:959-969.

Havea, P. 2006. Protein interactions in milk protein concentrate powders. Int. Dairy J. 16:415-422.

Kuramoto, S., R. Jenness, S. T. Coulter, and R. P. Choi. 1959. Standardization of the Harland-Ashworth test for whey protein nitrogen. J. Dairy Sci. 42:28-38.

Lin, Y., A. L. Kelly, J. A. O'Mahony, and T. P. Guinee. 2018. Effects of milk heat treatment and solvent composition on physicochemical and selected functional characteristics of milk protein concentrate. J. Dairy Sci. 101:6799-6813.

Manji, B., and Y. Kakuda. 1987. Determination of whey protein denaturation in heat-processed milks: Comparison of three methods. J. Dairy Sci. 70:1355-1361.

Martin, G. J. O., R. P. W. Williams, and D. E. Dunstan. 2010. Effect of manufacture and reconstitution of milk protein concentrate powder on the size and rennet gelation behaviour of casein micelles. Int. Dairy J. 20:128-131.

McCarthy, N. A., O. Power, H. B. Wijayanti, P. M. Kelly, L. Mao, and M. A. Fenelon. 2017. Effects of calcium chelating agents on the solubility of milk protein concentrate. Int. J. Dairy Technol. 70:1-9.

Mimouni, A., H. Deeth, A. Whittaker, M. J. Gidley, and B. R. Bhandari. 2010. Investigation of the microstructure of milk protein concentrate powders during rehydration: Alterations during storage. J. Dairy Sci. 93:463-472.
Mimouni, A., H. C. Deeth, A. K. Whittaker, M. J. Gidley, and B. R. Bhandari. 2009. Rehydration process of milk protein concentrate powder monitored by static light scattering. Food Hydrocoll. 23:1958-1965.

Oldfield, D., M. Taylor, and H. Singh. 2005. Effect of preheating and other process parameters on whey protein reactions during skim milk powder manufacture. Int. Dairy J. 15:501-511.

Pearce, R. 1995. Food functionality: Success or failure for dairy based ingredients. Aust. J. Dairy Technol. 50:15-23.

Sanderson, W. 1970. Seasonal variations affecting the determination of the whey protein nitrogen index of skim milk powder. N. Z. J. Dairy Sci. Technol. 5:48-52.

Schokker, E. P., J. S. Church, J. P. Mata, E. P. Gilbert, A. Puvanenthiran, and P. Udabage. 2011. Reconstitution properties of micellar casein powder: Effects of composition and storage. Int. Dairy J. 21:877-886.

Sikand, V., P. S. Tong, and J. Walker. 2008. Impact of protein standardization of milk powder with lactose or permeate on whey protein nitrogen index and heat classification. Dairy Sci. Technol. $88: 105-120$

Sikand, V., P. S. Tong, J. Walker, T. Wang, and L. E. RodriguezSaona. 2016. Short communication: Effect of storage temperature on the solubility of milk protein concentrate 80 (MPC80) treated with $\mathrm{NaCl}$ or KCl. J. Dairy Sci. 99:1791-1795.

Singh, H. 2011. Heat stability of milk. Int. J. Dairy Technol. 57:744749

Vasbinder, A. J., and C. G. de Kruif. 2003. Casein-whey protein interactions in heated milk: The influence of $\mathrm{pH}$. Int. Dairy J. 13:669-677. 